\title{
OPTIMIZATION OF GALACTO-OLIGOSACHARIDES SYNTHESIS USING RESPONSE SURFACE METHODOLOGY
}

\author{
Milica B. Carević», Katarina M. Banjanac, Ana D. Milivojević, Marija M. Ćorović, Dejan I. Bezbradica \\ University of Belgrade, Faculty of Technology and Metallurgy, Department of Biochemical Engineering \\ and Biotechnology, 11000 Belgrade, Karnegijeva 4, Serbia
}

\author{
${ }^{*}$ Corresponding author: \\ Phone: +381113303724 \\ Fax: +381113370387 \\ E-mail address: mcarevic@tmf.bg.ac.rs
}

\begin{abstract}
Galacto-oligosaccharides (GOS) are important lactose-derived compounds, considered to be a prebiotics, based on abundant scientific evidence about their unique physical properties and physiological effects. This consequently allows their widespread application as supplement in food and feed industry. They are preferably produced by the enzymatic transgalactosylation action of $\beta$ galactosidase. However, this enzyme simultaneously performs its primary biological function of lactose hydrolysis, and it is of crucial importance to gain an insight into the influence of different reaction conditions, and provide favorization of transgalactosylation, particularly GOS synthesis reaction. In this study, the response surface methodology (RSM) was applied in terms of individual experimental factors effect estimation, their mutual interaction identification and finally, the determination of optimum conditions for highest GOS yield achievement. Having said that, it can be observed that the temperature and $\mathrm{pH}$ have no significant impact on the GOS yield, while on the other hand, the lactose concentration of $400 \mathrm{~g} / \mathrm{l}$, enzyme concentration of $13.5 \mathrm{~g} / \mathrm{l}$ and reaction time of $13 \mathrm{~min}$ represent the optimum conditions for achieving the highest GOS yields.
\end{abstract}

Key words: galacto-oligosaccharides, $\beta$-galactosidase, Aspergillus oryzae, optimization, response surface methodology

\section{INTRODUCTION}

Nowadays an increased awareness considering the beneficial effects of functional foods and prebiotics on human health provided an extensive research focused on their production. Focusing on highly potent and widely available substrates, investigations led to the promising area of lactose based product development, allowing its upgrading and better utilization (Chen and Ganzle, 2016; Geiger et al., 2016).

Lactose conversion into desirable prebiotic and functional food ingredients is mainly achieved by enzymatic reaction of trans- galactosylation catalyzed by $\beta$-galactosidases (Gosling et al., 2010; Otieno, 2010). Although primarily regarded as hydrolyzing enzyme, widely used in the dairy industry for lactose hydrolysis, $\beta$-galactosidase under specific conditions can as well perform galactosyl moiety transfer to another carbohydrate, namely lactose, resulting in the formation of a complex mixture of highly valuable products named galacto-oligosaccharides (GOS) (Torres et al., 2010).

GOS represent a diverse group of water soluble carbohydrates consisting of several galactose and usually one terminal glu- 
cose unit, that can notably vary in polymerization degree, type of linkages, and more importantly in their properties (Urrutia et al., 2013, Carević et al., 2016a). They are marked as non-digestible compounds, recognized as prebiotics owing to the fact that are selectively metabolized by some favorable intestinal microbiota, particularly bifidobacteria and lactobacilli, providing their proliferation and promotion of their activity (Arreola et al., 2014; Hong et al., 2016). GOS may also cause inhibition of intestinal pathogen growth via disabling their adhesion to gastrointestinal epithelial cell surface (Shoaf et al., 2006; Sinclair et al., 2004). Having said that, their consumption greatly contributes to the human overall wellbeing, since they are believed to support an improvement of lactose digestion and mineral absorption, reduction of serum cholesterol level, diminishing the risk of cancer, and enhancement of the host's immune system (Sangwan et al., 2011; Macfarlane et al., 2008; Bruno-Barcena and Azcarate-Peril, 2015). Besides, GOS feature various other favorable characteristics such as the high acid stability, low caloric value, excellent taste and relatively low sweetness that make them highly applicable in infant milk formulas, dairy products, beverages, and finally, animal feed (Van Leusen et al., 2014).

Enzymatic synthesis of GOS from lactose using $\beta$-galactosidase from different sources (bacteria, yeasts and fungi) has already been studied by many authors (Torres et al., 2010). Generally, the transgalactosylation reaction was described as a kinetically controlled reaction, where substrate conversion, productivity and product distribution can be highly dependent on the reaction conditions and the enzyme properties (Mahoney, 1998; Park and Oh, 2011). The $\beta$-galactosidase from Aspergillus oryzae, used throughout this study, was previously studied in GOS synthesis, and it proved to be enzyme of choice, prevalently because of its high specific activity, good thermal stability and more importantly low cost (Vera et al., 2012). However, shear of lactose being converted into GOS is fairly low, indicating the need of detailed experimental conditions optimization. Several papers dealing with opti- mization of reaction parameters, focusing on one at a time, were published so far, focusing mostly on the influence of varying lactose concentration on the GOS formation (Huerta et al., 2011; Vera et al., 2011). In general, it was observed that an increment of lactose content, as well as enzyme content, favor GOS formation (Huerta et al., 2011; Warmerdam, et al., 2013). However, temperature and $\mathrm{pH}$ showed a different impact on synthesis yield and product distribution in different reaction systems, although they highly affect reaction productivity (Park and Oh, 2011). On the other hand, extensive optimization comprising all individual and mutual effects of several key factors is very scarce (Lisboa et al., 2012). Therefore, the aim of this study was to achieve thorough optimization of GOS synthesis taking both effects of key reaction parameters (lactose and enzyme concentration, temperature and $\mathrm{pH}$, and reaction time), and their mutual interactions at the same time. For this purpose, response surface methodology (RSM) was employed, and two response variables were monitored (lactose conversion degree and GOS yield).

\section{MATERIAL AND METHODS}

\section{Materials}

$\beta$-Galactosidase from $A$. oryzae (>8 IU/mg solid) and lactose used in this study were purchased from Sigma Chemical Co. (St. Louis, MO, USA). HPLC analysis was performed using HPLC grade water purchased from JT Baker (Center Valley, PA, USA). Other reagents, used for buffer solution preparations, were of analytical grade, and purchased from Centrohem (Stara Pazova, Serbia).

\section{Production of galacto-oligosaccharides}

All reactions were performed in conical flasks on an orbital shaker (IKA ${ }^{\circledR}$ KS 4000i control, Werke $\mathrm{GmbH}$ and Co.) set at 200 RPM under the controlled temperature specified by experimental plan. Reaction mixtures were comprised of lactose and an enzyme (concentrations specified for each experiment) which were dissolved in $5 \mathrm{ml}$ of the suitable buffer. Samples were taken at different times, predetermined by the experimental plan, and the reaction 
was stopped by heating samples at $100{ }^{\circ} \mathrm{C}$ for $10 \mathrm{~min}$ in order to inactivate the enzyme. Samples were appropriately diluted with HPLC grade water, centrifuged (12000 rpm for $10 \mathrm{~min}$ ), filtered through a $0.2 \mu \mathrm{m}$ syringe filter and then analyzed by high performance liquid chromatography (HPLC). All experiments were carried out in duplicate and the average values (provided that the standard deviations were less than $5 \%$ ) of the product concentrations were used for further analysis. Results were presented as the lactose conversion degree (Equation 1) and GOS yield (Equation 2).

Throughout this study, the GOS concentration represents the sum of trisaccharides (GOS3) and tetrasaccharides (GOS4), since the concentration of higher oligosaccharides was negligible (Carević et al, 2016b).

\section{Experimental design and statistical analysis}

Experiments were conducted using a central composite rotatable design (CCRD) for the study of five factors (lactose concentration, enzyme concentration, temperature, $\mathrm{pH}$ and reaction time) each at five levels (Table 1). Ranges for these parameters are chosen on the basis of preliminary experiments or thorough literature survey. The experimental plan consisted of 32 experiments (16 factorial, 10 axial, and 6 center points) performed in random order to minimize systematic errors (Milisavljević et al., 2014). The data obtained were analyzed by a response surface method (RSM) to fit the second-order polynomial equation (Equation 3 ).

Where $Y$ is the response variable (lactose conversion degree and product concentration), $b_{0}, b_{i}, b_{i i}, b_{i j}$, are the regression coefficients, and $X_{i}$ and $X_{j}$ are independent variables (Table 1 ). The least-squares method was employed for the response function coefficient calculation and their statistical significance evaluation. Only the significant terms $(p \leq 0.05)$ were considered for the final reduced model. Adequacy of the obtained model was determined by the Fisher test. Student distribution was used to evaluate the significance of the coefficients. MATLAB 7.0 (Mathworks Inc., Natrick, USA) was used for this purpose.

\section{High performance liquid chromato- graphy analysis}

Quantitative analysis of the samples was performed using a Dionex Ultimate 3000 (Thermo Scientific, Waltham, MA, USA) HPLC system equipped with a Thermo Scientific carbohydrate column (Hyper REZ XP Carbohydrate $\mathrm{Ca}^{2+}, 300 \mathrm{~mm} \times 7.7$ $\mathrm{mm}$, i.d. $8 \mu \mathrm{m}$ ) working at $80^{\circ} \mathrm{C}$. HPLC grade water was used as the mobile phase with the constant elution rate of 0.6 $\mathrm{ml} / \mathrm{min}$ during the analysis, and the detection was performed by a $\mathrm{RI}$ detector ( $\mathrm{Re}$ fractoMax 520, ERC, Riemerling, Germany). All data acquisition and processing were done using Chromeleon ${ }^{\mathrm{TM}} 7.2$ Chromatography Data System (Thermo Scientific).

Lactose conversiondegree $(\%)=\frac{\text { Initiallactoseconcentrafon }- \text { lactoseconcentrafion in sample }}{\text { Initial lactoseconcentrafon }} \times 100 \%$

GOS yield $(\%)=\frac{\text { GOS concentrafon }}{\text { Initial lactose concentrafion }- \text { lactose concentrafon in the sample }} \times 100 \%$

$Y=b_{0}+\sum_{i=1}^{5} b_{i} X_{i}+\sum_{i=1}^{5} b_{i i} X_{i}^{2}+\sum_{i, j, i j j}^{5} b_{i j} X_{i} X_{j}$

Table 1.

Experimental factors

\begin{tabular}{lccccc}
\hline \multirow{2}{*}{ Independent variables } & \multicolumn{5}{c}{ Coded/Actual values } \\
& -2 & -1 & 0 & 1 & 2 \\
\hline Temperature, $\mathrm{X}_{1}\left({ }^{\circ} \mathrm{C}\right)$ & 40 & 45 & 50 & 55 & 60 \\
Lactose concentration, $\mathrm{X}_{2}(\mathrm{~g} / \mathrm{l})$ & 20 & 115 & 210 & 305 & 400 \\
Enzyme concentration, $\mathrm{X}_{3}(\mathrm{~g} / \mathrm{l})$ & 1 & 4,5 & 8 & 11,5 & 15 \\
Time (min) & 1 & 6 & 11 & 16 & 21 \\
$\mathrm{pH}$ & 3.5 & 4.25 & 5 & 5.75 & 6.5 \\
\hline
\end{tabular}




\section{RESULTS AND DISCUSSION}

As already noted, $\beta$-galactosidase is traditionally used in the dairy industry as a lactose hydrolyzing enzyme. However, in recent years more attention is paid to its transgalactosylation activity, which enables the production of a series of compounds with a prominent functional activity, named galacto-oligosaccharides (GOS). Interestingly, these reactions take place at the same time, and the first stage of these reactions (lactose cleavage) is common, and it represents the formation of enzyme-galactosyl complex (Figure 1).

From this point on, reaction course faces a divergence. If enzyme-galactosyl complex passes the galactose moiety onto the molecule of water, the reaction of hydrolysis occurs, and on the other hand, if galactose moiety is passed onto any other free hydroxyl group (lactose or a lower galacto-oligosaccharide molecule), the reaction of transgalactosylation occurs (Figure 1). The rates of all these reactions and consequently the final reaction mixture composition, depend on type of enzyme and reaction conditions such as enzyme and lactose concentration, temperature and the characteristics of the reaction medium (Torres et al., 2010).

Moreover, it should be pointed out that GOS do not represent end products, and that they are susceptible to hydrolysis too (Mahoney, 1998). Thus, the determination of the optimum reaction time is essential, since hydrolysis of GOS inevitably occurs in later stages of the reaction, due to their significant concentration in the reaction mixture. Having said that, it is clear that GOS synthesis represents a rather difficult task, and therefore, the effect of key reaction factors (lactose and enzyme concentration, temperature and $\mathrm{pH}$, and reaction time) should be evaluated and optimized using response surface methodology (RSM).

Typical chromatograms, presented in an overlapped display in Figure 2, represent the progress of the reaction. With the proceeding of the reaction course, lactose peak $\left(t_{R}=9.627 \mathrm{~min}\right)$ is continuously reducing, while the peaks of its primary hydrolysis products, namely glucose $\left(t_{R}=10.953\right.$ min) and galactose $\left(t_{R}=12.042 \mathrm{~min}\right)$, are increasing. However, due to its incurporation in GOS, as consequence of transgalactosylation, galactose peak and consequently its concentration is significantly lower than glucose concentration.

Products of transgalactosylation are depicted by trisaccharide (GOS3) peak $\left(t_{R}=8.733 \mathrm{~min}\right)$ and tetrasaccharide (GOS4) peak $\left(t_{R}=8.213 \mathrm{~min}\right)$. In our previous study (Carević et al., 2016a) was confirmed by IMS/MS-MS analysis that other disaccharides, except the lactose, are not pre-sent in the reaction mixture and that GOS3 and GOS4 peaks exclusively with $\beta(1 \rightarrow 6)$ and $\beta(1 \rightarrow 3)$ glycosidic linkages are the only transgalactosylation products.

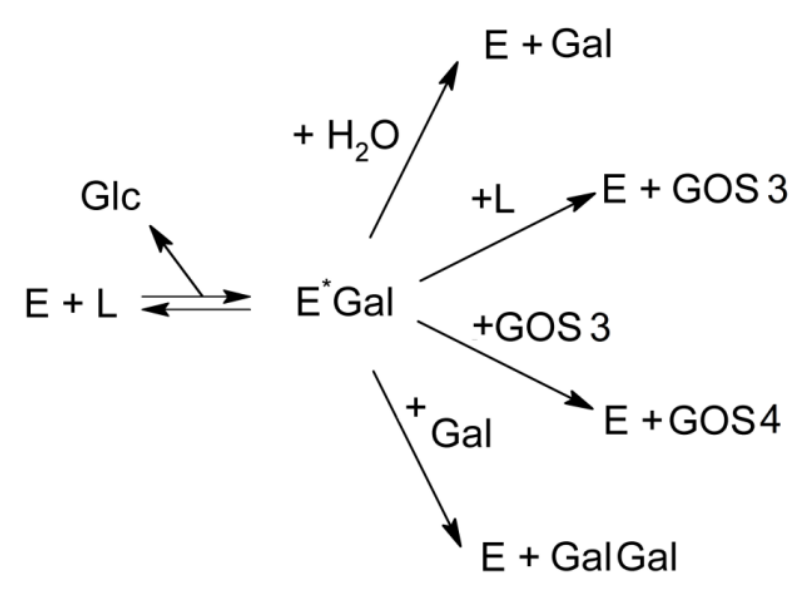

Figure 1. Reaction mechanism of galacto-oligosaccharides synthesis 


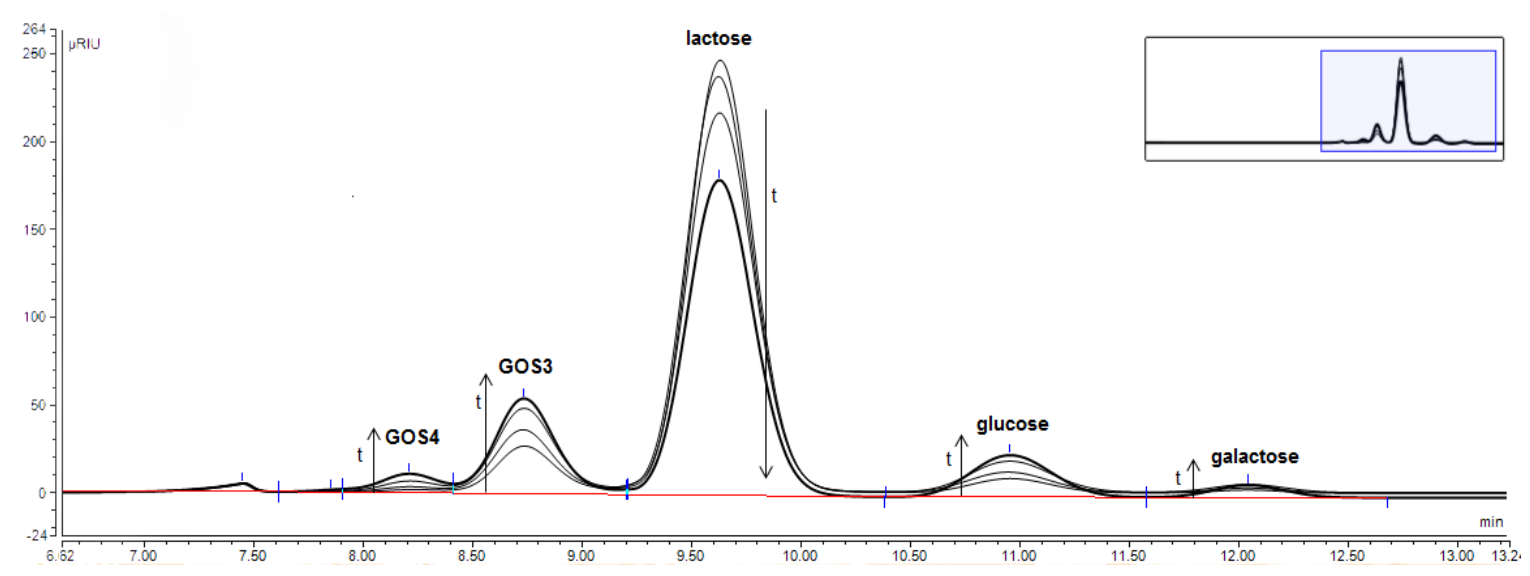

Figure 2. Overlapped chromatograms of reaction species during the reaction course

$Y_{1}=43.30+3.60 X_{1}-12.60 X_{2}+9.21 X_{3}+11.80 X_{4}-2.57 X_{5}-1.70 X_{1}^{2}-4.37 X_{3}^{2}-3.41 X_{5}^{2}+2.74 X_{1} X_{4}$

$-2.29 X_{2} X_{3}+3.31 X_{2} X_{5}$

Hence, calculated concentrations of these peaks are used as output data in subsequent RSM optimization.

The aim of the first stage of RSM optimization was to estimate the effect of reaction parameters on the lactose conversion degree. The results were fitted with second-order regression model. Good correlation between experimental results and regression model was determined using the Fisher test, and then Student test was performed in order to evaluate the significance of model coefficients. After the elimination of insignificant coefficients regression model (Equation 4) was obtained.

As it can be clearly seen from the equation, all the linear regression coefficients are significant. On the other hand, three quadratic regression coefficients, namely $b_{11}(-1.70), b_{33}(-4,37)$ and $b_{55}(-3,41)$, are significant and negative, hence, the influence of corresponding parameters: temperature, enzyme concentration and $\mathrm{pH}$ can be described as a quadratic function with a maximum value. Moreover, it is evident that there are several significant interactions between the examined parameters: positive interactions between temperature $\left(X_{1}\right)$ and time $\left(X_{4}\right)$, and lactose concentration $\left(X_{2}\right)$ and $\mathrm{pH}$ value of reaction mixture $\left(X_{5}\right)$, and, on the other hand, negative interaction between the lactose
$\left(X_{2}\right)$ and enzyme $\left(X_{3}\right)$ concentration. The influences of these experimental factors on the lactose conversion are presented as response surface diagrams (Figure 3 ).

The Figure $3 A$ shows the influence of the temperature $\left(X_{1}\right)$ and the reaction time $\left(X_{4}\right)$ on the lactose conversion degree. It can be observed that the temperature can be described as a quadratic function with a maximum. Yet, it can be noted that the position of the local maximum varies significantly depending on the reaction time. Hence, in short reaction times, a maximum lactose conversion is achieved at $44{ }^{\circ} \mathrm{C}$, although the temperature shows a negligible impact on lactose conversion yield.

On the other hand, at maximum reaction times the temperature plays an important role, and maximum lactose conversion degree is achieved around $60{ }^{\circ} \mathrm{C}$. As already mentioned, the effects of $\mathrm{pH}$ on the lactose conversion degree can be described as a quadratic function with a maximum value, and this dependence is depicted in Figure 3B. It can be observed that the maximum conversion degree is achieved when the $\mathrm{pH}$ value persist around $\mathrm{pH}$ 4.0. Nevertheless, it should be noted that the position of local maximum is highly dependent on the lactose concentration due to the significant interaction between these two parameters. Since this interaction is positive, a shift of local ma- 
ximum values towards higher values at higher lactose concentrations is caused. However, lactose concentration $\left(X_{2}\right)$ has negative influence on the lactose conversion degree, and therefore lower lactose concentrations and consequently lower values of $\mathrm{pH}$ are preferred in terms of achieving the highest conversion degrees. Moreover, the lactose concentration shows the combined effect with another parameter, namely enzyme concentration $\left(X_{3}\right)$. This interaction is depicted in Figure $3 C$. Since square regression coefficient $b_{33}$ is significant and has a negative value, the impact of the concentration of the enzyme is described as a quadratic function with a maximum.
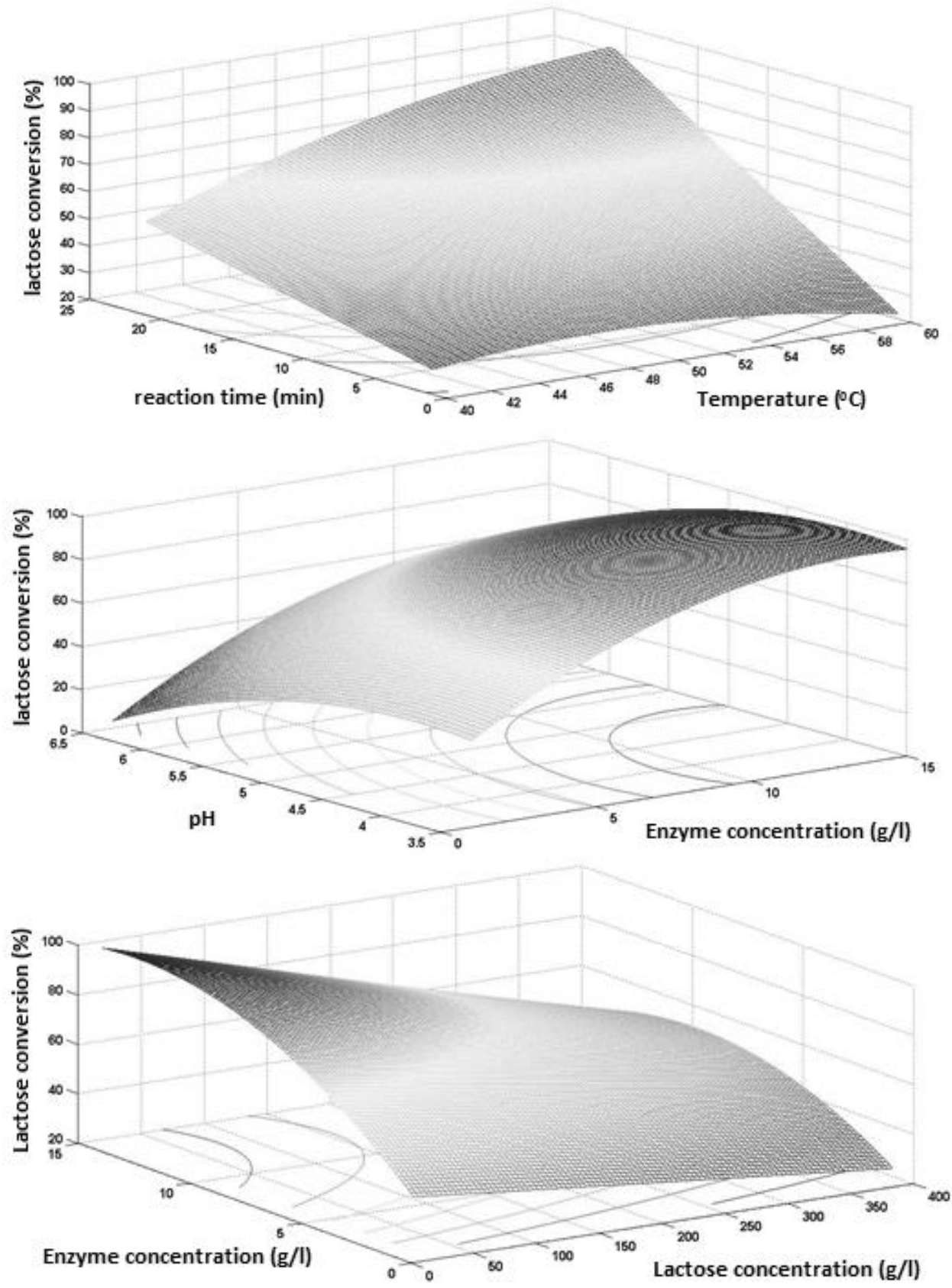

Figure 3. The response surface plots: $(A)$ interactive effect of reaction time and temperature on the lactose conversion. Other factors were fixed at: $X_{2}=-1 ; X_{3}=0, X_{5}=0$, (B) interactive effect of $p H$ and enzyme concentration on the lactose conversion. Other factors were fixed at: $X_{1}=0, X_{2}=-2, X_{4}=1$, (C) interactive effect of enzyme concentration and lactose concentration on the lactose conversion.

Other factors were fixed at: $X_{1}=1 ; X_{4}=2, X_{5}=1$ 
Due to the existence of the negative interaction with lactose concentration, position of the local optimum enzyme concentration moves toward higher values with decreasing concentration of lactose.

As previously mentioned, at higher initial concentrations of lactose conversion degree did not show significant growth, even with optimum values of enzyme concentrations.

On the other hand, at lower concentration values lactose, the increase in the lactose conversion degree with increasing concentrations of the enzyme is notable.

Bearing this in mind, it can be concluded that the greatest degree of lactose conversion is achieved at a concentration of enzymes around $13.5 \mathrm{~g} / \mathrm{l}$, provided that the lactose concentration is around $20 \mathrm{~g} / \mathrm{l}$. Finally, these results lead to the conclusion that in order to achieve the maximum lactose conversion degree, optimal conditions should be: temperature $60^{\circ} \mathrm{C}$, a lactose concentration of $20 \mathrm{~g} / \mathrm{l}$, enzyme concentration of $13.5 \mathrm{~g} / \mathrm{l}$, reaction time 25 min and $\mathrm{pH} 4$.

Even though the high portion of lactose conversion was achieved, only one part goes on GOS synthesis while the rest is a consequence of hydrolysis, where lactose is converted to its constituents (glucose and galactose).

Therefore, the influence of the same reaction parameters on the promotion of GOS synthesis was examined.
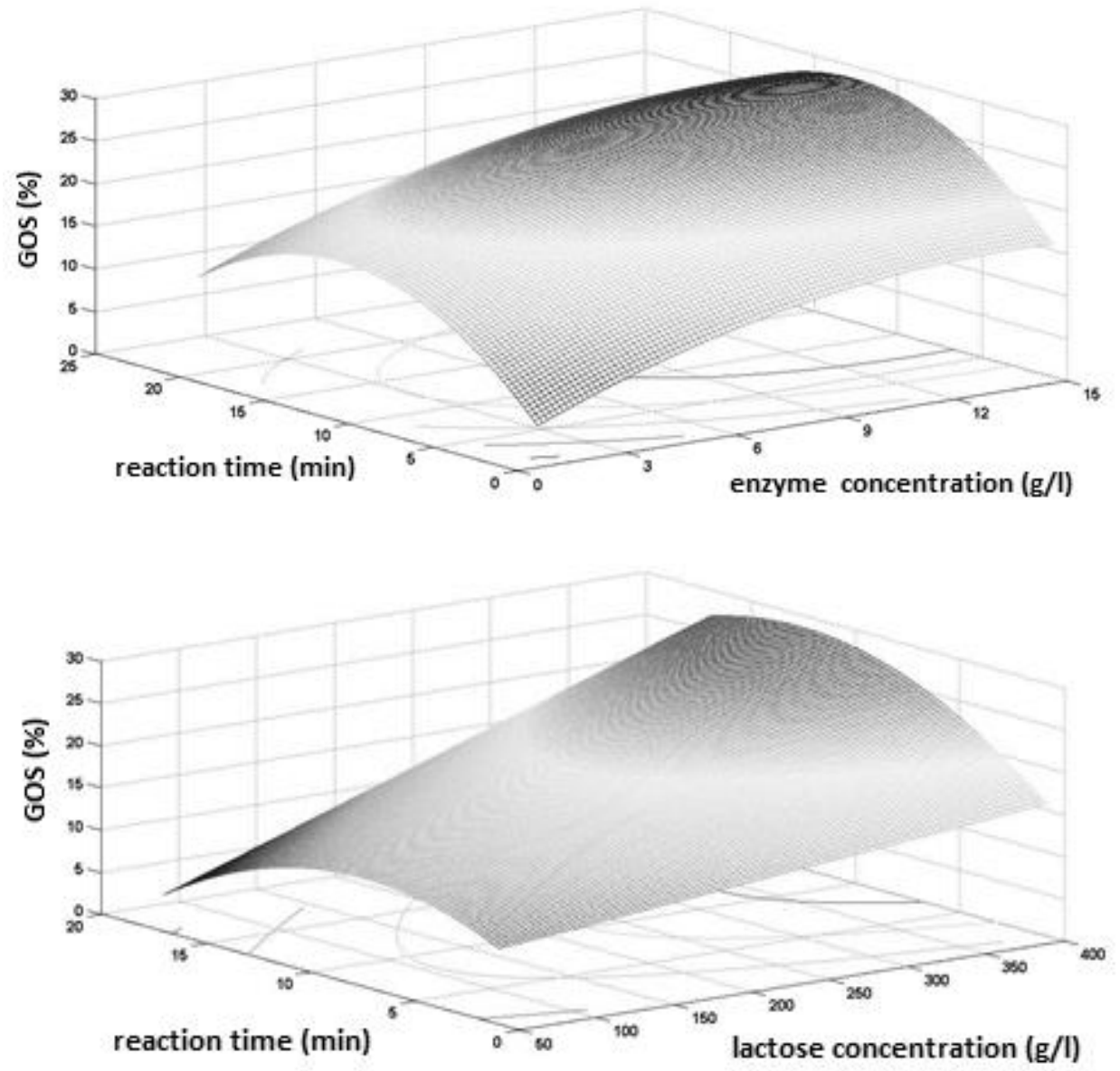

Figure 4. The response surface plots: (a) interactive effect of reaction time and enzyme concentration on the GOS yield. Other factors were fixed at: $X_{2}=2,(b)$ interactive effect of reaction time and lactose concentration on the GOS yield. Other factors were fixed at: $X_{3}=2$

$Y_{2}=21.70+2.01 X_{2}+0.41 X_{3}-1.06 X_{4}-0.83 X_{3}^{2}-2.34 X_{4}^{2}+1.23 X_{2} X_{3}+1.34 X_{2} X_{4}$ 
After the employing the previously defined statistical analysis a new regression model was derived (Equation 5).

Unlike the first derived model (Equation 4), the second model (Equation 5) shows that not all of the linear regression coefficients are significant. Consequently, not all the reaction parameters showed significant impact on the GOS synthesis reaction. More precisely, temperature $\left(\mathrm{X}_{1}\right)$ and $\mathrm{pH}$ $\left(\mathrm{X}_{5}\right)$ in the examined range proved to be insignificant factors, while the other factors (lactose concentration, enzyme concentration and reaction time), played an important role in maximizing a GOS yield. As it can be seen from the model, there are two significant quadratic regression coefficients $b_{33}(-0.83)$ and $b_{44}(-2.34)$, and both of them have negative values, meaning they possess an optimum value. Also, it was found that there is a positive correlation between the lactose $\left(X_{2}\right)$ and enzyme concentration $\left(X_{3}\right)$, as well as the positive correlation between the lactose concentration $\left(X_{2}\right)$ and the reaction time $\left(X_{4}\right)$.

Influences of the most interesting factors on the obtained GOS yield are illustrated on the response surface diagrams (Figure 4). As noted before, the influence of the enzyme concentration $\left(X_{3}\right)$ can be graphically presented as a quadratic function with a maximum value, due to the negative quadratic regression coefficient. Local maximum peaks, however, may vary greatly depending on the initial lactose concentration, due to the positive interaction between these two factors. Hence, local optimum values of the enzyme concentration shift towards higher values at higher lactose concentrations. Likewise, the effect of the reaction time $\left(X_{4}\right)$ can be described as a quadratic function with a maximum, and owing to the positive correlation with the lactose concentration it shifts towards higher optimum values, as lactose concentration increases. Unlike these two factors, lactose concentration increase causes the increment of GOS yield in whole examined range. Having said that, it can be concluded that the optimum values of observed parameters in terms of achieving the highest GOS yields, were: lactose concentration of $400 \mathrm{~g} / \mathrm{l}$, enzyme concen- tration of $13.5 \mathrm{~g} / \mathrm{l}$ and reaction time of 13 min. If we compare the obtained models, as well as the results of the optimization concerning both examined outputs, significant differences can be observed. Obviously, the individual factors showed substantial impact onto the reaction course. More precisely, it was shown that the key reaction parameters are the concentration of lactose and reaction time, as the impact of these factors on the two outputs diametrically opposite. Most importantly, the high concentration of lactose and low reaction times favor the transgalactosylation reaction, hence GOS synthesis. These results are somehow expected, bearing in mind that higher lactose concentrations provide more sugar molecules that can compete with water molecules leading to increase in GOS production, while the lower lactose concentrations shift the reaction course towards hydrolysis. Likewise, in the initial stage of the reaction transgalactosylation is promoted due to the high lactose concentration in the reaction mixture. In later stages, however, the intensified hydrolysis of both lactose and GOS takes place, thus longer reaction times are not fitted for GOS synthesis.

Finally, in terms of testing the adequacy of the obtained optimization results, an additional experiment was performed under the following conditions: lactose concentration of $400 \mathrm{~g} / \mathrm{l}$, enzyme concentration of $13.5 \mathrm{~g} / \mathrm{l}$ and reaction time of $13 \mathrm{~min}$, temperature $50{ }^{\circ} \mathrm{C}$ and $\mathrm{pH} 4.5$. The obtained GOS yield in this case was $29.6 \%$, that represents less than $5 \%$ deviation from the predicted value by the RSM model.

\section{CONCLUSIONS}

In the present study, the surface response methodology (RSM) was employed for the reaction parameter (temperature, enzyme and lactose concentration, reaction time and $\mathrm{pH}$ ) optimizations in terms of achieving high GOS yields catalyzed by $\beta$ galactosidase from Aspergillus oryzae. It was concluded that the temperature and $\mathrm{pH}$, although they highly impact the lactose conversion, have negligible influence on GOS synthesis. While, on the other hand, enzyme concentration, lactose con- 
centration and time provide a rather significant contribution to the optimization process. More precisely, highest GOS yields are achieved when reaction parameters are as follows: lactose concentration of $400 \mathrm{~g} / \mathrm{l}$, enzyme concentration of $13.5 \mathrm{~g} / \mathrm{l}$ and reaction time of $13 \mathrm{~min}$. Bearing in mind that GOS yields achieved in the additional experiment under the optimum conditions, are within 5\% deviation from the predicted values, it can be concluded that model ensures good prediction, and that application of RSM was reasonable.

\section{ACKNOWLEDGEMENTS}

The authors are grateful for financial support from the Serbian Ministry of Education, Science, and Technological Development (Project III 46010).

\section{REFERENCES}

1. Arreola, S.L., Intanon, M., Pham, N.H., Haltrich, D., Nguyen, T.-H. (2014). Galacto-oligosaccharides recent progress on research and application as prebiotics. In Galactose: Structure and Function in Biology and Medicine. Nova Science Publishers, Inc., New York, pp. 75-105.

2. Bruno-Barcena, J.M., Azcarate-Peril, M.A. (2015) Galacto-oligosaccharides and colorectal cancer: Feeding our intestinal probiome. Journal of Functional Foods, 12, 92-108.

3. Carević, M., Bezbradica, D., Banjanac, K., Milivojević, A., Fanuel, M., Rogniaux, H., Ropartz, D., Veličković, D. (2016a). Structural elucidation of enzymatically synthesized galacto-oligosaccharides using ion-mobility spectrometrytandem mass spectrometry. Journal of Agricultural and Food Chemistry, 64, 3609-3615.

4. Carević, M., Ćorović, M., Mihailović, M., Banjanac, K., Milisavljević, A., Veličković, D., Bezbradica, D. (2016b). Galacto-oligosaccharide synthesis using chemically modified $\beta$-galactosidase from Aspergillus oryzae immobilised onto macroporous amino resin. International Dairy Journal, 54, 50-57.

5. Chen, X.Y., Gänzle, M.G. (2017). Lactose and lactose-derived oligosaccharides: More than prebiotics? International Dairy Journal, 67, 6172.

6. Geiger, B., Nguyen, H.M., Wenig, S., Nguyen, H.A., Lorenz, C., Kittl, R., Mathiesen, G., Eijsink, V.G.H., Haltrich, D., Nguyen, T.-H. (2016). From by-product to valuable components: Efficient enzymatic conversion of lactose in whey using $\beta$-galactosidase from Streptococcus thermophilus. Biochemical Engineering Journal, 116, 45-53.

7. Gosling, A., Stevens, G.W., Barber, A.R., Kentish, S.E., Gras, S.L. (2010). Recent advances refining galactooligosaccharide production from lactose. Food Chemistry, 121, 307-318.

8. Hong, K.B., Kim, J.H., Kwon, H.K., Han, S.H., Park, Y., Suh, H.J. (2016). Evaluation of prebiotic effects of high-purity galactooligosaccharides in vitro and in vivo. Food Technology and Biotechnology, 54, 156-163.

9. Huerta, L.M.; Vera, C.; Guerrero, C.; Wilson, L.; Illanes, A. (2011). Synthesis of galactooligosaccharides at very high lactose concentrations with immobilized $\beta$-galactosidases from Aspergillus oryzae. Process Biochemistry, 46, 245-252.

10. Lisboa, C.R., de Simoni Martinez, L., Trindade, R.A., de Almeida Costa, F.A., de Medeiros Burkert, J.F., Burkert, C.A.V. (2012). Response surface methodology applied to the enzymatic synthesis of galacto-oligosaccharides from cheese whey. Food Science and Biotechnology, 6, 1519-1524.

11. Macfarlane, G.T., Steed, H., Macfarlane, S. (2008) Bacterial metabolism and health related effects of galacto-oligosaccharides and other prebiotics. Journal of Applied Microbiology, 104, 305-344.

12. Mahoney, R.R. (1998). Galactosyl-oligosaccharide formation during lactose hydrolysis: A review. Food Chemistry, 63, 147-154.

13. Milisavljević, A., Stojanović, M., Carević, M., Mihailović, M., Veličković, D., Milosavić, N., Bezbradica, D. (2014). Lipase-catalyzed esterification of phloridzin: Acyl donor effect on enzymatic affinity and antioxidant properties of esters. Industrial and Engineering Chemistry Research, 53, 16644-16651.

14. Otieno, D.O. (2010). Synthesis of $\beta$-galactooligosaccharides from lactose using microbial $\beta$-galactosidases. Comprehensive Reviews in Food Science and Food Safety, 9, 471-482.

15. Park, A.-R., Oh, D.-K. (2010). Galactooligosaccharide production using microbial $\beta$ galactosidase: Current state and perspectives. Applied Microbiology and Biotechnology, 85, 1279-1286.

16. Sangwan, V., Tomar, S.K., Singh, R.R.B., Singh, A.K., Ali, B. (2011). Galactooligosaccharides: Novel components of de-signer foods. Journal of Food Science, 76, 103-111.

17. Shoaf, K., Mulvey, G.L., Armstrong, G.D., Hutkins, R.W. (2006) Prebiotic galacto-oligosaccharides reduce adherence of enteropathogenic Escherichia coli to tissue culture cells. Infection and Immunity, 74, 6920-6928.

18. Sinclair, H.R., De Slegte, J., Gibson, G.R., Rastall, R.A. (2009) Galacto-oligosaccharides (GOS) inhibit Vibrio cholerae toxin binding to its GM1 receptor. Journal of Agricultural and Food Chemistry, 57, 3113-3119.

19. Torres, D.P., Gonçalves, M., Teixeira, J.A., Rodrigues, L.R. (2010). Galacto-oligosaccharides: Production, properties, applications, and significance as prebiotics. Comprehensive Reviews in Food Science and Food Safety, 9, 438-454.

20. Urrutia, P., Rodriguez-Colinas, B., FernandezArrojo, L., Ballesteros, A. O., Wilson, L., Illanes, A., Plou, F.J. (2013). Detailed analysis of ga- 
lactooligosaccharides synthesis with $\beta$-galactosidase from Aspergillus oryzae. Journal of Agricultural and Food Chemistry, 61, 10811087.

21. Van Leusen, E., Torringa, E., Groenink, P., Kortleve, P., Geene, R., Schoterman, M., Klarenbeek, B. (2014). Industrial Applications of Galactooligosaccharides. In Food Oligosaccharides: Production, Analysis and Bioactivity, Wiley-Blackwell, Hoboken, pp. 470-491.

22. Vera, C., Guerrero, C., Illanes, A. (2011). Determination of the transgalactosylation activity of Aspergillus oryzae $\beta$-galactosidase: Effect of
$\mathrm{pH}$, temperature, and galactose and glucose concentrations. Carbohydrate Research, 346, 745-752.

23. Vera, C., Guerrero, C., Conejeros, R., Illanes, A. (2012). Synthesis of galacto-oligosac-charides by $\beta$-galactosidase from Aspergillus oryzae using partially dissolved and supersaturated solution of lactose. Enzyme and Microbial Technology, 50, 188- 194.

24. Warmerdam, A., Boom, R.M., Janssen, A.E.M. (2013). $\beta$-Galactosidase stability at high substrate concentrations. SpringerPlus, 2, 402-410.

\title{
ОПТИМИЗАЦИЈА СИНТЕЗЕ ГАЛАКТО-ОЛИГОСАХАРИДА ПОМОЋУ МЕТОДА ОДЗИВНИХ ПОВРШИНА
}

\author{
Милица Б. Царевић*, Катарина М. Бањанац, Ана Д. Миливојевић, Марија М. Ћоровић, \\ Дејан И. Безбрадица
}

Универзитет у Београду, Технолошко-металуршки фракултет, Катедра за биохемијско инжењерство и биотехнологију, 11000 Београд, Карнегијева бр. 4, Србија

Сажетак: Галакто-олигосахариди (ГОС) обухватају разнородну групу несварљивих угљених хидрата, деривата лактозе, који се сматрају пребиотицима захваљујући бројним научним студијама у којима су доказана њихова изузетна фризичко-хемијска, као и физиолошка својства. Ова сазнања омогућила су њихову широку примену у прехрамбеној и фрармацеутској индустрији, као и у индустрији сточне хране. Галакто-олигосахариди се скоро искључиво производе ензимском синтезом помоћу ензима $\beta$-галактозидазе. Међутим, познато је да овај ензим истовремено обавља и своју основну биолошку функцију, а то је хидролиза лактозе, па је од пресудног значаја стећи увид у утицај различитих реакционих фактора, и на тај начин омогућити фраворизовање реакције трансгалактозилације, односно синтезе галактоолигосахарида. У овој студији, у циљу испитивања утицаја појединачних реакционих параметара, уочавања и разумевања њихових међусобних ефреката и на крају одређивања оптималних услова за повећан принос галакто-олигосахарида, примењени су методи статистичког планирања експеримената и метод одзивних површина (RSM). Коначно, након анализе резултата примећено је да температура и $\mathrm{pH}$ немају значајан утицај на принос галактоолигосахарида, док су са друге стране оптималне вредности сигнификантних фактора: концентрација лактозе $400 \mathrm{~g} / \mathrm{l}$, концентрација ензима 13,5 g/l и време 13 минута.

Кључне речи: галакто-олигосахариди, $\beta$-галактозидаза, Aspergillus oryzae, оптимизација, метод одзивних површина

Received: 6 March 2017

Accepted: 13 April 2017 